\title{
Acute HTLV-1 leukemia/ lymphoma in a 33 year old grenadian migrant: A case report
}

Hubert Daisley Jr, Oneka Acco, Solange De Noon

Department of Pathology, General Hospital San Fernando, San Fernando, Trinidad and Tobago

Corresponding author: Prof. Hubert Daisley, E-mail: profhdjr@yahoo.com

\begin{abstract}
We present a case of an acute HTLV-1 leukemia in a 33-year-old Grenadian immigrant. Her diffuse skin nodules, and her coming from an area endemic for HTLV-1, namely the Caribbean made the clinical diagnosis of HTLV-1 leukemia/ lymphoma more feasible. Her disease was rapidly progressive, she having survived for one month, and fits into the acute classification of ATLL as proposed by Shimyoyama M. Immigrants from areas endemic for HTLV-l who presents with skin rashes should be investigated for HTLV-l neoplasms.
\end{abstract}

Key words: HTLV-1 leukemia/lymphoma; Skin manifestation; Endemic areas; Migrants

\section{INTRODUCTION}

HTLV-1 is a retrovirus which is associated with HAM/TSP [1-3] and which causes leukemia/ lymphoma [4].

The neoplastic process presents in the early stages with a skin lesion as the primary site $[5,6]$ and progresses to the advance stages with multiple organs involvement of the reticuloendothelial system such as the liver, spleen, and, bone marrow. There are indeed other presentations as in the case in discussion that presented as an acute leukemia with diffuse skin involvement.

\section{CASE REPORT}

A 33-year-old Grenadian national was on a six months visit to Trinidad when she developed a generalized pruritic skin rash and abdominal pain following consumption of shrimps. She visited the General Hospital for the above complain three days following the above symptoms.

On examination she was found to be icteric and with pale mucous membrane. Her pulse was $80 / \mathrm{min}$, blood pressure $90 / 60 \mathrm{~mm} \mathrm{Hg}$, respiratory rate $15 / \mathrm{min}$ and temperature $36.5^{\circ} \mathrm{C}$.
She was not in discomfort. She had generalized nodules distributed on the upper and lower limbs, chest and face (Figs. 1 and 2). They were non-erythematous, and non-tender. No cervical, axillary or inguinal lymph nodes were palpable.

She was mildly tender in the left hypochondrium, with a markedly palpable spleen.

Her genitourinary and central nervous systems examination were essentially normal. She was started on analgesic and antipruritic oral medications and was admitted to the medical ward for further investigation.

Laboratory investigations revealed an $\mathrm{Hb}$ of $7.5 \mathrm{~g} / \mathrm{dl}$ (11.7-15.5), hematocrit of 27.1\%. (9 34.5-46.30), MCHC $27.6 \mathrm{~g} / \mathrm{dl}$ (342.5-35.2), MCV $83 \mathrm{fl}(80-40-95.5)$ MCH 22.9 pg. (27.2-33.5), WBC $131.610 \wedge 3 /$ UL (4.10-11.20), with 83.6\% Lymphocytes. (18.850.8), 13.3\% (39.9-73.9) Neutrophils, 7.9\% (0.3-1.8) Basophils, 0.1\% (0.9-6.0) Eosinophils, 2.9\% (0.3-0.9) Monocytes, platelets $263 \times 10^{\wedge} 3 / \mathrm{UL}$. (159-388.0). There were polylobated lymphocytes, " flower cell "in the peripheral blood smear, but no hairy cells or blasts. She was hypercalcaemic, calcium $13.1 \mathrm{mg} / \mathrm{dl}, \mathrm{Na}+127 \mathrm{mmol} / \mathrm{L}$., K+ $4.8 \mathrm{mmol} / \mathrm{L}$.,

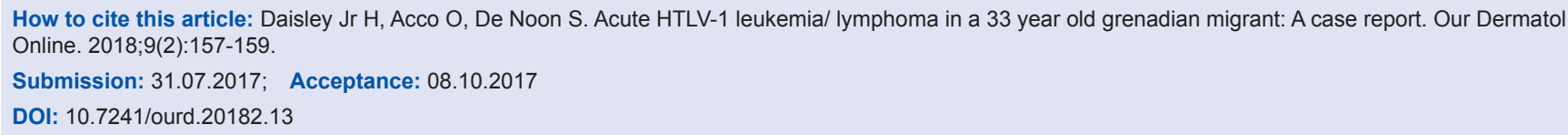




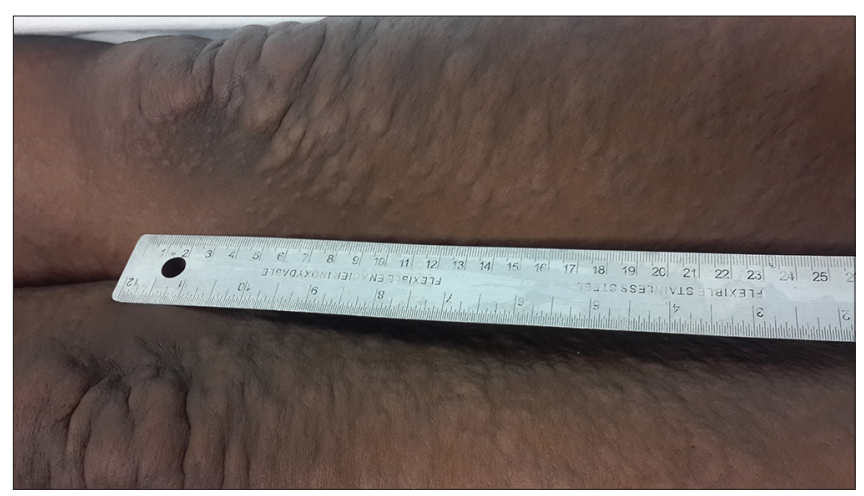

Figure 1: Skin nodules in the lower extremities.

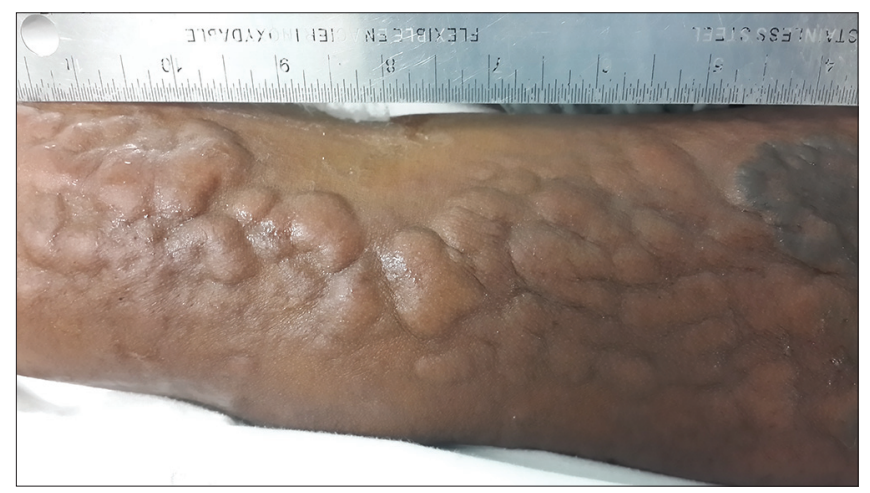

Figure 2: Higher magnification of skin nodules.

Chloride 90 mmol/L., AST 91 IU/L., ALT 16 IU/L., LDH 2901 U/L) 135-225), GGT 68 U/L., Alkaline phosphatase $123 \mathrm{U} / \mathrm{L}$., Total protein $6.0 \mathrm{~g} / \mathrm{dl}$, Albumin $3.3 \mathrm{~d} / \mathrm{dl}$, Globulin $2.7 \mathrm{gm} / \mathrm{dl}$ (3.5-5.5), Total Bilirubin $4.6 \mathrm{mg} / \mathrm{dl}$, direct bilirubin $1.2 \mathrm{mg} / \mathrm{dl}$, indirect bilirubin $3.4 \mathrm{mg} / \mathrm{dl}$.

A bone marrow aspirate and trephine biopsy showed an infiltrate of malignant T-lymphocytes. There were no blast cells.

A skin biopsy of the nodule revealed a moderate infiltrate of small to medium sized lymphocytes with pleomorphic nuclei and sparse minute eosinophilic nucleoli arranged in a nodular fashion involving the dermis and subcutaneous tissue (Fig. 3). Admixed with this lymphocytic infiltrate were histiocytic cells (Fig. 4). Epidermotropism was absent.

The lymphocytes expressed T-cell markers with CD3, CD5, and CD4 positivity and were negative for CD7 and CD34.

Her HTLV-l was positive. She was started on hydroxyurea and referred to the oncologist for further management.

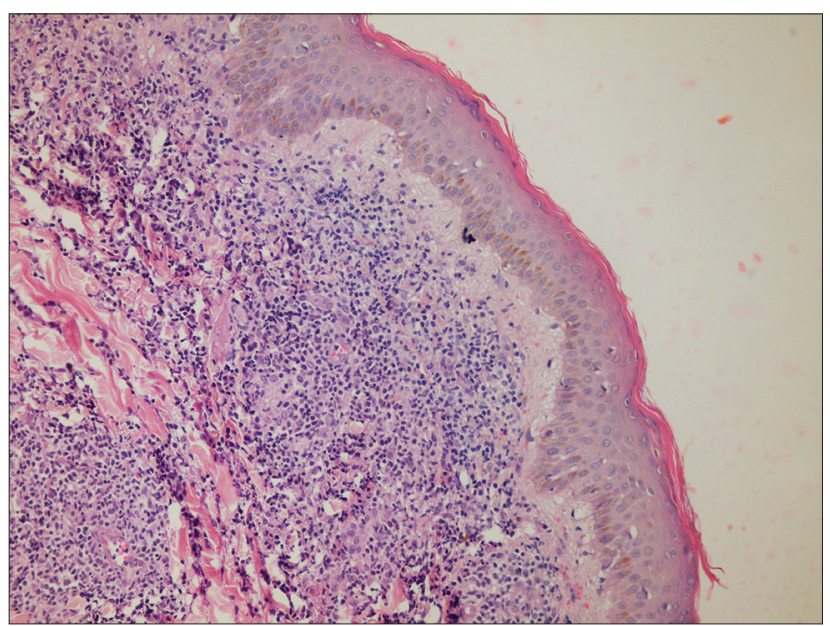

Figure 3: The sections show skin with hyperkeratosis. Within the dermis is a nodular infiltrate of atypical lymphocytes which is separated from the epidermis by a grenz. zone.

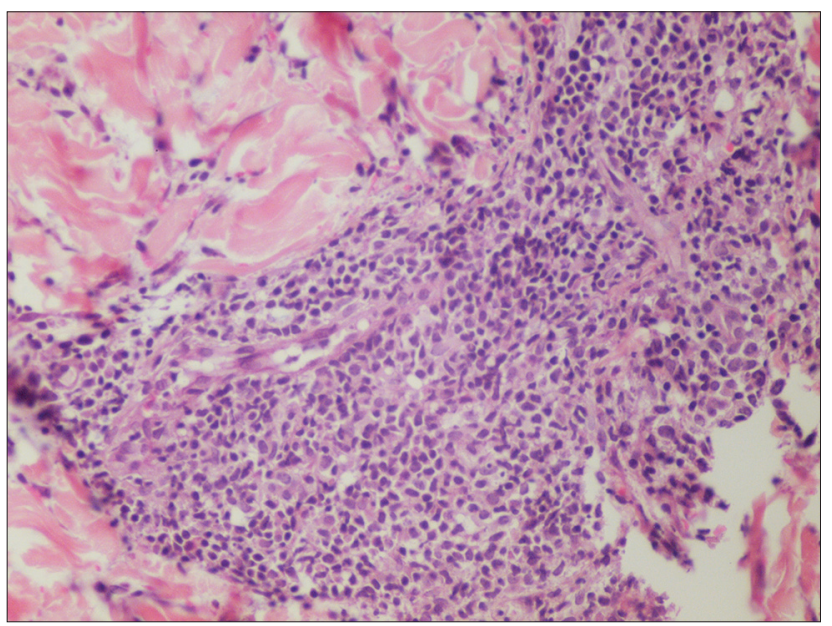

Figure 4: At higher magnification the atypical infiltrate was that of a T-cell lymphoma which is composed of small and medium size lymphocytes with pleomorphic nuclei and sparse eosinophilic nucleoli. Mitoses were infrequent. Admixed with these lymphoma cells were histiocytic cells.

The patient died one month after diagnosis while undergoing chemotherapy.

\section{DISCUSSION}

Human T-cell Lymphotrophic virus-1 is endemic in the Caribbean, Japan $[7,8]$ and is seen now in most countries amongst immigrants from endemic countries $[9,10]$.

The virus causes HAM/TSP and is the causative agent of HTLV-1 leukemia/lymphoma [1].

The acute, chronic, smoldering and lymphoma are the four different clinical manifestations of the neoplasm that have been identified [2]. 
We describe here a Grenadian national who presented in Trinidad W.I with splenomegaly and an acute HTLV1 leukemia, having a white blood cell count of $131 \mathrm{x}$ $10^{\wedge} 3 / \mathrm{UL}$ with $83.6 \%$ atypical lymphocytes within the peripheral blood and a diffuse nodular skin lesion which histologically contained malignant HTLV-l infiltrate. Hairy cell leukemia and chronic myeloid leukemia both have splenomegaly of the magnitude seen in this patient. However these two leukemia were eliminated from the diagnosis on account of the HTLV-l positivity, the immuonhistology of the malignant cells, the absence of hairy cells and myeloblast in the peripheral blood and bone marrow aspirate. The skin nodules were composed of malignant infiltrate of HTLV-l cells, which had no correlation with the consumption of shrimps. In addition to the lymphocytosis, she also presented with hypercalcaemia and a markedly elevated LDH, which are poor prognostic markers. This patient only survived one month after diagnosis.

HTLV-l skin manifestation are varied and includes infective dermatitis, maculo-papular hyper pigmented or hypo pigmented rashes, nodules or ill-defined rashes, which mimics Mycosis fungoides, Psoriasis, Eczema and a list of common dermatoses, [11] and may be an early presentation of this neoplastic disease entity $[5,6]$.

Clinicians should have a high index of suspicion of HTLV-l related disease in patients from endemic regions who presents with a skin rash.

\section{CONCLUSION}

HTLV-l is endemic in the Caribbean and Japan. Immigrants presenting with a skin rash from endemic regions should be investigated for HTLV-1 Leukemia/ Lymphoma and it's other related diseases [12].

\section{REFERENCES}

1. Gessain A, Cassar O. Epidemiological Aspects and World Distribution of HTLV-1 Infection. Front Microbiol. 2012;3:388.

2. Shimoyama M. Diagnostic criteria and classification of clinical subtypes of adult T-cell leukemia-lymphoma. A report from the Lymphoma Study Group (1984-87). Br J Haematol. 1991;79:428-37.

3. Oh U, Jacobson S. Treatment of HTLV-I-associated myelopathy/ tropical spastic paraparesis: toward rational targeted therapy. Neurolog Clinics. 2008;26:781-97.

4. Giam C, Semmes JO. HTLV-1 Infection and Adult T-Cell Leukemia/Lymphoma-A Tale of Two Proteins: Tax and HBZ. Viruses 2016;8:161.

5. Daisley H. Charles W, De Noon S. HTLV-1 Lymphomas, the Skin and its histiogenisis. GAV J Case Report. 2016;2016:17-21.

6. Goncalves DU, Guedes AC, Cameiro-Proietti AB, Lambertucci JR. HTLV-1 associated infective dermatitis may be an indolent HTLV-1 associated lymphoma. Braz J Infect Dis. 2000;4:1000-2.

7. Adedayo O, Grell G, Bellot P. Hospital admissions for human T-cell lymphotrophic virus type-1 (HTLV-1) associated diseases in Dominica. Postgrad Med J. 2003;79:341-4.

8. Maekawa K, Moriguchi-Goto S, Kamiunten A, Kubuki Y, Shimoda K, Takeshima $\mathrm{H}$, et al. Primary central nervous system lymphoma in Miyazaki, southwestern Japan, and a human T-lymphotropic virus Type-1 (HTLV-1) -endemic area: clinicopathological review of 31 cases. J Clin Exp Hematop. 2014;54:179-85.

9. Levine PH, Dosik H, Joseph EM, Felton S, Bertoni MA, et al. A study of adult T-cell leukemia/lymphoma incidence in central Brooklyn. Int J Cancer. 1999;80:662-6.

10. Vitone F, Gibellini D, Schiavone P, D'Antuono A, Gianni L, Bon I, et al. Human T-lymphotropic virus type 1 (HTLV-1) prevalence and quantitative detection of DNA proviral load in individuals with indeterminate/positive serological results. BMC Infect Dis. 2006;6:41.

11. Okajima R, Oliveria ACP, Smid J, Casseb J, Sanches JA. High prevalence of Skin Disorders among HTLV-1 infected individuals independent of clinical status. PLOS Negl Trop Dis. 2013;7:e246.

12. Watanabe T. HTLV-1 associated diseases. Int J Hematol. 1997;66:257-78.

Copyright by Hubert Daisley $\mathrm{Jr}$, et al. This is an open-access article distributed under the terms of the Creative Commons Attribution License, which permits unrestricted use, distribution, and reproduction in any medium, provided the original author and source are credited. Source of Support: Nil, Conflict of Interest: None declared. 